\title{
Untangling causes of variation in mercury concentration between flight feathers ${ }^{\text {मै }}$
}

\author{
Marie Claire Gatt ${ }^{\mathrm{a}, ~}{ }^{*}$, Ricardo Furtado ${ }^{\mathrm{b}}$, José Pedro Granadeiro ${ }^{\mathrm{a}}$, Daniel Lopes ${ }^{\mathrm{b}}$, \\ Eduarda Pereira ${ }^{\mathrm{c}}$, Paulo Catry ${ }^{\mathrm{b}}$ \\ a Centro de Estudos Do Ambiente e Do Mar(CESAM), Departamento de Biologia Animal, Faculdade de Ciencias da Universidade de Lisboa, 1749-016, Lisboa, \\ Portugal \\ ${ }^{\mathrm{b}}$ Marine and Environmental Sciences Centre (MARE), ISPA - Instituto Universitário, Rua Jardim Do Tabaco 34, 1149-041, Lisbon, Portugal \\ ${ }^{c}$ Laboratório Associado para a Química Verde (LAQV-REQUIMTE), Departmento de Quimica, Universidade de Aveiro, 3810-193, Aveiro, Portugal
}

\section{A R T I C L E I N F O}

\section{Article history:}

Received 16 October 2020

Accepted 15 November 2020

Available online 18 November 2020

\section{Keywords:}

Biomonitoring

Feather

Mercury

Pollution

Seabirds

\begin{abstract}
A B S T R A C T
Bird feathers are one of the most widely used animal tissue in mercury biomonitoring, owing to the ease of collection and storage. They are also the principal excretory pathway of mercury in birds. However, limitations in our understanding of the physiology of mercury deposition in feathers has placed doubt on the interpretation of feather mercury concentratoins. Throughout the literature, moult sequence and the depletion of the body mercury pool have been taken to explain patterns such as the decrease in feather mercury from the innermost (P1) to the outermost primary feather (P10) of the wing. However, it has been suggested that this pattern is rather a measurement artefact as a result of the increased feather mass to length ratio along the primaries, resulting in a dilution effect in heavier feathers. Here, we attempt to untangle the causes of variation in feather mercury concentrations by quantifying the mercury concentration as $\mu \mathrm{g}$ of mercury (i) per gram of feather, (ii) per millimetre of feather, and (iii) per day of feather growth in the primary feathers of Bulwer's Petrel Bulweria bulwerii chicks, effectively controlling for some of the axes of variation that may be acting in adults, and monitoring the growth rate of primary feathers in chicks. The mercury concentration in Bulwer's Petrel chicks' primaries increased from the innermost to the outermost primary for all three concentration measures, following the order of feather emergence. These observations confirm that the pattern of mercury concentration across primary feathers is not an artefact of the measure of concentration, but is likely an effect of the order of feather growth, whereby the earlier grown feathers are exposed to higher blood mercury concentrations than are later moulted feathers as a result of blood mercury depletion.
\end{abstract}

(C) 2020 Elsevier Ltd. All rights reserved.

\section{Introduction}

The use of wildlife as biomonitors of mercury is routine in order to quantify mercury pollution and the associated bioaccumulation risks to the health of humans and other animals (Chételat et al., 2020). Several tissues, particularly of top predators in both the marine and terrestrial ecosystems, have been targeted for mercury quantification, but one of the most practical and widely used is probably bird feathers (Albert et al., 2019; Appelquist et al., 1984; Burger, 1994; Furness et al., 1986; Thompson et al., 1998).

\footnotetext{
This paper has been recommended for acceptance by Professor Christian Sonne.

* Corresponding author.

E-mail address: mcgatt57@gmail.com (M.C. Gatt).
}

Feathers are complex, inert keratin structures (Crewther et al., 1965) which are disconnected from the bird's blood circulation once fully grown. For this reason, and since they are moulted seasonally, feathers can be sampled from live birds relatively nonintrusively and non-destructively. They are the most important excretory pathway of mercury in birds, which is deposited in the form of methyl mercury during feather growth (Braune and Gaskin, 1987; Lewis and Furness, 1991; Monteiro and Furness, 2001). Mercury bound within feathers is then stable with respect to environmental exposure (Appelquist et al., 1984). As a result, feathers do not require specific storage conditions, making them favourable over blood and tissue samples in remote field conditions (Appelquist et al., 1984).

Knowledge of the moult sequence of feathers, coupled with information on the movement ecology of a species, has been used to determine mercury exposure at specific temporal and spatial 
scales (Gatt et al., 2020; Mallory et al., 2015; Ramos et al., 2009a; Watanuki et al., 2015). However, the physiological mechanisms controlling feather mercury deposition are not well known (Bortolotti, 2010), and this may have important consequences on data interpretation. Across avian taxa, mercury concentration in primary feathers is often seen to decrease from the innermost (P1) to the outermost primary (P10) (Furness et al., 1986; Martínez et al., 2012; Peterson et al., 2019). Throughout the literature, this pattern has been explained as a result of moult sequence and the depletion of the body mercury pool (Braune and Gaskin, 1987; Carravieri et al., 2014; Dauwe et al., 2003; Furness et al., 1986; Thompson et al., 1998). However, it has been suggested that this pattern is rather a measurement artefact as a result of the increased feather mass to length ratio along the primaries, resulting in a dilution effect in heavier feathers (Bortolotti, 2010). The latter is based on the argument that mercury deposition into feathers is dependent on the amount of time that the growing feather is exposed to the blood circulation (time-dependent deposition), and is not bound to the feather in a mass-dependent fashion. Without a better understanding of the mechanisms controlling mercury deposition into feathers, interpretation of feather mercury may be unreliable or spurious (Bond, 2010).

Here, we attempt to untangle the causes of variation in feather mercury concentrations by quantifying the mercury concentration in the primary feathers of seabird chicks, effectively controlling for some of the axes of variation that may be acting in adults. Bulwer's Petrels Bulweria bulwerii are small, nocturnal, mesopelagic predators, which breed in large numbers on Deserta Grande, Madeira, in the east Atlantic Ocean (Waap et al., 2017). They experience a fledging period of 61 days on average and a fledging success usually above $80 \%$ (Nunes, 2000). Adult Bulwer's Petrels act as central place foragers during the breeding period, which spans between April and September (Nunes and Vicente, 1998). As a result, chicks are exposed to mercury contamination from the parents' provisioning trips within a restricted geographical range around the colony (Chaurand and Weimerskirch, 1994; Shoji et al., 2015; Wischnewski et al., 2019).

Chicks grow their flight feathers simultaneously at the nest (Nunes and Vicente, 1998). If moult sequence determines feather mercury concentration in adults, we would expect chick primary feathers to have similar mercury concentrations, reflecting their simultaneous growth. If inter-feather differences persist in simultaneously grown feathers, other factors must be at play.

Bortolotti (2010) proposed that measuring the concentration of mercury as $\mu \mathrm{g}$ of mercury per gram of feather induces artefacts as a result of the variation in the length-to-weight ratio of feathers of various sizes and shapes and the time-dependent deposition of mercury into growing feathers, suggesting mercury concentration as $\mu \mathrm{g}$ of mercury per millimetre of feather as an alternative to control for this. Here, we designed an analysis protocol that allows for the quantification of the mass of feather mercury per millimetre of feather to test this hypothesis. If any pattern seen in mercury concentration expressed as $\mu \mathrm{g}$ of mercury per gram of feather persists under this new concentration measurement then the trend in mercury concentration across primaries is not a direct artefact of this phenomenon.

Although the rate of wing growth has been assessed for Bulwer's Petrels (Nunes and Vicente, 1998), individual flight feather growth rate has not. In addition to collecting primary feathers from Bulwer's Petrel chicks found dead, we also measured the growth rate of primary feathers in live chicks to be able to calculate the mass of mercury deposited per day of feather growth in each feather, which should be a more accurate representation of the time-dependent deposition of mercury in flight feathers (Roque et al., 2016).

\section{Methods}

\subsection{Fieldwork}

Fieldwork was carried out on the island nature reserve of Deserta Grande, Madeira, Portugal $\left(32^{\circ} 30^{\prime} 48^{\prime \prime} \mathrm{N}, 16^{\circ} 30^{\prime} 33^{\prime \prime} \mathrm{W}\right)$. Deserta Grande hosts one of the largest Bulwer's Petrel populations of the Atlantic (Catry et al., 2015), with a large number of accessible nests on the site of the field station.

During the chick-rearing period of 2018, a large number of nests were monitored regularly as part of another study. Nine dead chicks with advanced primary feather growth were encountered and the primary feathers from their right wing were collected whole.

Primary feather growth rates were measured in live chicks. The primary feathers of the right wing of 14 chicks were measured every four days using a pin-ruler from 28 days of age until 60 days of age.

\subsection{Sample preparation and analysis}

The sampled whole primary feathers were weighed and measured (total length and vane length). In order to be able to calculate the concentration of mercury expressed per gram of feather as well as per millimetre of feather length (Bortolotti, 2010), five consecutive $8 \mathrm{~mm}$-long segments from each primary feather (P1 - P10) were cut perpendicularly to the rachis (Fig. 1). These

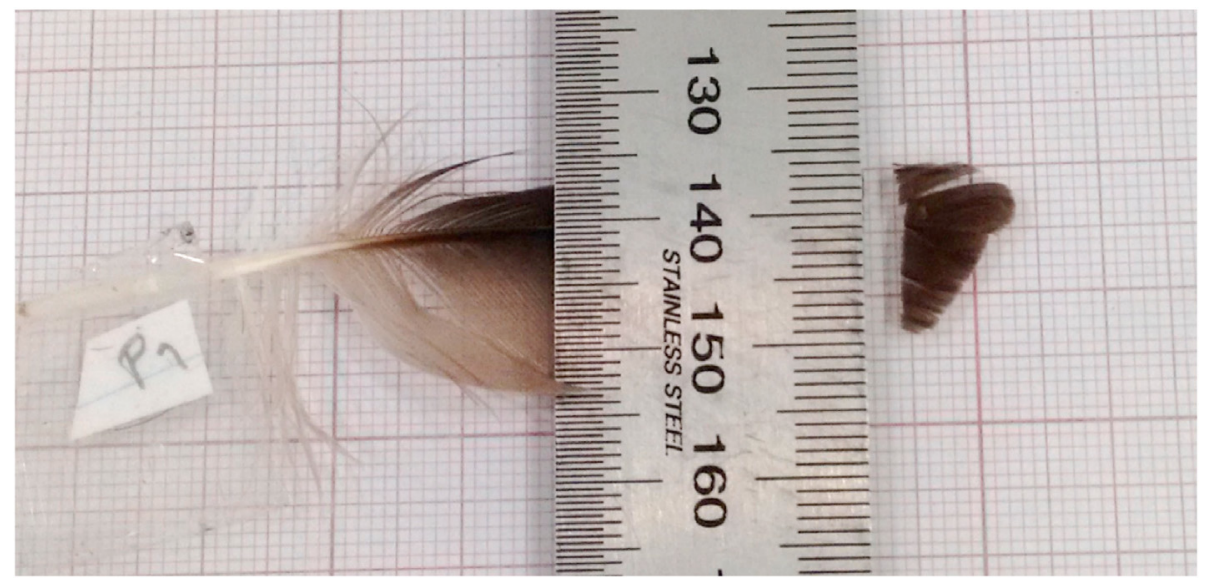

Fig. 1. The line of dissection of the outermost segment ( $8 \mathrm{~mm}$ of tip) on the innermost primary feather (P01) of a Bulwer's Petrel chick. 
segments were analysed whole for total mercury, after being weighed. Total mercury was quantified using thermal decomposition atomic absorption spectrometry with gold amalgamation on a LECO AMA-254. Certified reference material (TORT-3) was analysed daily to ensure measurement accuracy and precision. The recovery efficiency was $87.91 \pm 13.41 \%(n=50)$. The average mercury concentration per feather was calculated from the mercury concentration values obtained from all segments successfully analysed from the respective feather (between 3 and 5 segments), expressed both per gram of feather as well as per millimetre of feather.

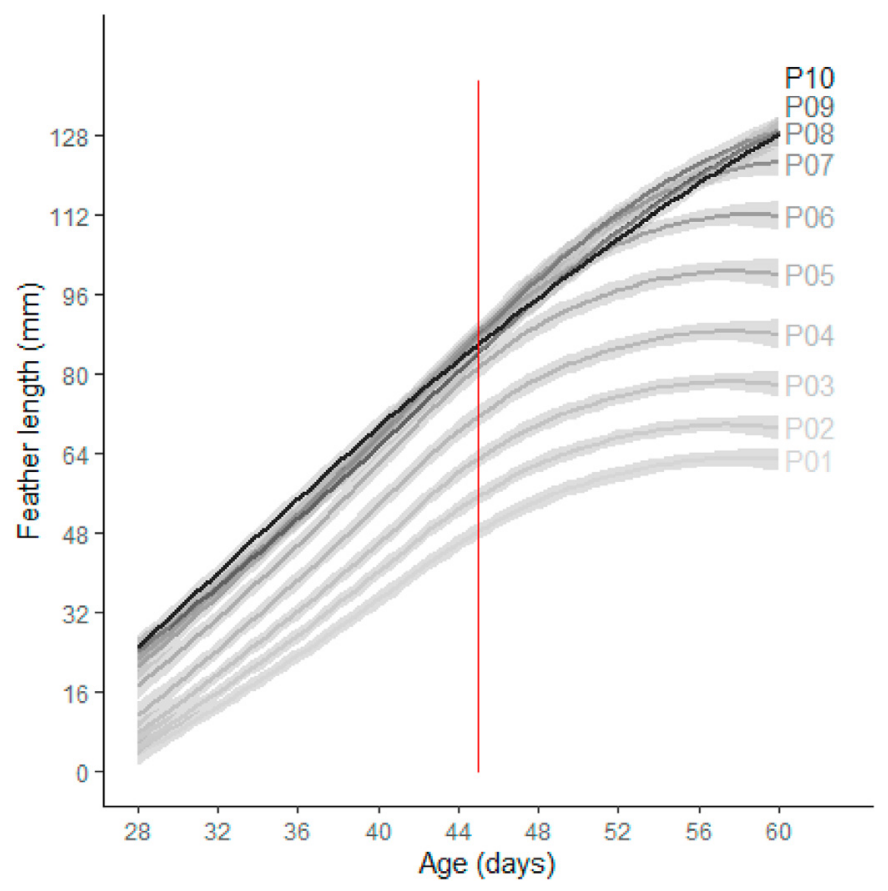

Fig. 2. The growth of primary feathers (P01 $-P 10)$ of juvenile Bulwer's Petrels $(n=14)$ between 28 and 60 days since hatching on Deserta Grande. The growth rate used in this study was calculated over the period between 28 and 45 days since hatching (red line). Shading indicates the confidence interval.

\subsection{Statistical analysis}

All statistical analysis was carried out using the $\mathrm{R}$ statistical software (R Core Team, 2019).

The growth rate for each primary feather was taken as the coefficient of a regression of feather length against chick age (in days) over the first 45 days of age, during which time feather growth is almost linear (Fig. 2). The length of feather analysed for mercury in chicks also corresponds to this growth period. The mass of mercury deposited per day of feather growth was calculated by multiplying the mercury concentration expressed per millimetre of each feather with the growth rate for the corresponding feather type.

Feather mercury concentrations (expressed as $\mu \mathrm{g}$ of mercury per gram of feather, per millimetre of feather, and per day of feather growth) were transformed to relative feather mercury, calculated as the deviation (\%) in a feather's mercury concentration from the mean feather mercury concentration over all analysed primaries for each individual.

We analysed the pattern of mercury concentration along the primaries using one-way ANOVA (function aov, package "stats"), relating relative feather mercury concentration to primary feather position. This was done for all three concentration measures of mercury in chick primaries.

We also assessed the pattern of feather mercury along the length of the feathers by comparing the mercury concentrations (expressed as $\mu \mathrm{g}$ of mercury per gram of feather and transformed to relative deviation from the mean mercury concentration across all primaries for each individual) of the consecutive segments analysed. The effect of feather segment on relative mercury was tested in a two-way ANOVA, including primary feather as an explanatory variable.

\section{Results}

\subsection{Chick primary growth rate}

Primary feather growth rates were calculated from measurements of 14 live chicks - all chicks survived to fledging. Growth rates differed between feathers and were similar between individuals (standard error of growth coefficients ranged between 0.08 and 0.11 ) (Fig. 3). Notably, outer feathers started growing
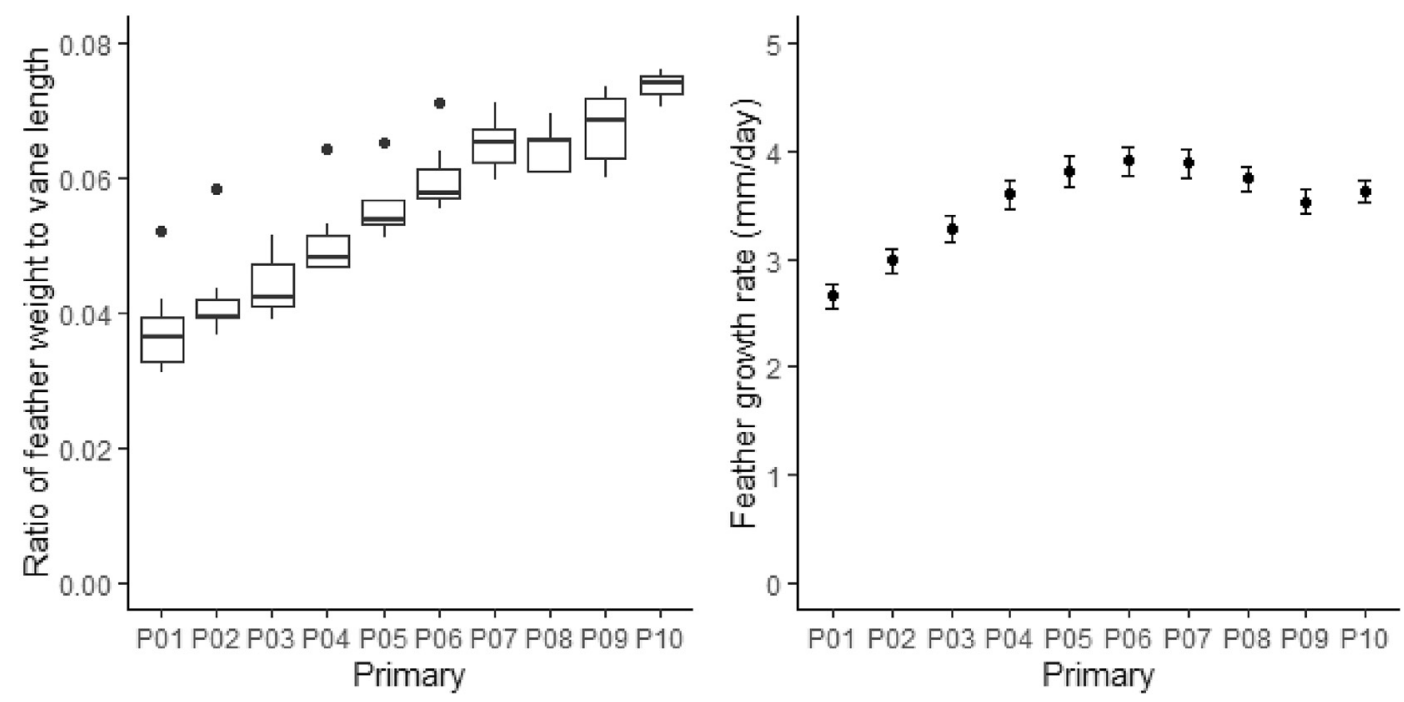

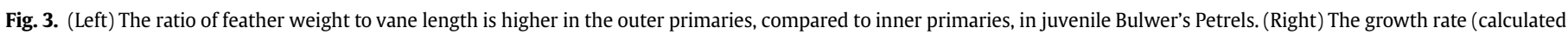
between 28 and 45 days since hatching) differs among primary feathers. Whiskers represent standard errors. 
before inner feathers, as apparent from the feather length at the start of observations (Fig. 2). The ratio of feather weight to vane length increases from the inner to outer primaries, as expected (Fig. 3).

\subsection{Primary feather mercury concentration}

We obtained mercury concentrations of between eight and ten primary feathers from eight Bulwer's Petrel chicks. The average mercury concentration across all samples was $1.94 \pm 0.56 \mu \mathrm{g} / \mathrm{g}$. Feather mercury concentration was significantly different among primary feathers (ANOVA results comparing mercury concentration expressed as $\mu$ g of mercury (i) per gram of feather: $F=8.88$, $p<0.001$, (ii) per millimetre of feather; $F=20.83, p<0.001$, (iii) per day of feather growth: $\mathrm{F}=40.76, \mathrm{p}<0.001$ ). The mercury concentration of chicks' primary feathers appears to increase from the innermost (P01) to the outermost (P10), with primary type having a significant effect on feather mercury concentration. This is opposite to what is generally seen in other birds, where mercury concentration is highest in the innermost primaries, which are moulted first in many avian species. The differences between feathers became more distinct when using measures that better reflected time-dependent deposition of mercury (Fig. 4).

Apart from the effect primary feather had on mercury concentration, mercury content also decreased along each feather $(\mathrm{F}=65.62, \mathrm{p}<0.001)$; the outermost segments of the earlier grown outer feathers have the highest mercury concentration, with the proximal segments of these feathers having similar mercury loads to the distal segments of the inner primaries (Fig. 5), which would be growing at around the same time (Fig. 2).

\section{Discussion}

Using data from chicks in which we monitored feather growth, we provide evidence that the pattern of mercury concentration across primary feathers is not an artefact of the measure of concentration, but is likely an effect of the order of feather growth, whereby the earlier grown feathers are exposed to higher blood mercury concentrations than are later moulted feathers as a result of blood mercury depletion.

In adult birds across diverse taxa, mercury concentration decreases from the innermost to the outermost primaries following the order of descendent primary moult (Accipitiformes: Sparrowhawk Accipiter nisus, Northern Goshawk Accipiter gentilis, Common Buzzard Buteo buteo; Strigiformes: Little Owl Athene noctua; Charadriiformes: Bonaparte's gulls Larus philadelphia, Great Skua Catharacta skua, Kittiwake Rissa tridactyla; Procellariiformes: Fulmar Fulmarus glacialis, Manx Shearwater Puffinus puffinus, Atlantic Petrel Pterodroma incerta, Soft-plumaged Petrel Pterodroma mollis, Kerguelen Petrel Aphrodroma brevirostris, Great Shearwater Ardenna gravis) (Braune and Gaskin, 1987; Dauwe et al., 2003; Furness et al., 1986; Martínez et al., 2012). Feather mercury concentration follows the chronology of feather moult even in the Peregrine Falcon Falco peregrinus, in which primary moult is divergent starting with P4 (Lindberg and Odsjö, 1983), but no obvious pattern is detected in the Barn Owl (Tyto alba, Dauwe et al., 2003; Roque et al., 2016) or Tawny Owl (Strix aluco, Varela et al., 2016) in which primary moult is arrested and irregular (Cramp and Simmons, 1985).

The mercury concentration in the primary feathers of Bulwer's Petrel chicks decreases from the outermost to the innermost primaries, along the order of feather growth. While the primaries of nestlings are growing simultaneously, they do not start growing at exactly the same time, with primary emergence occurring in
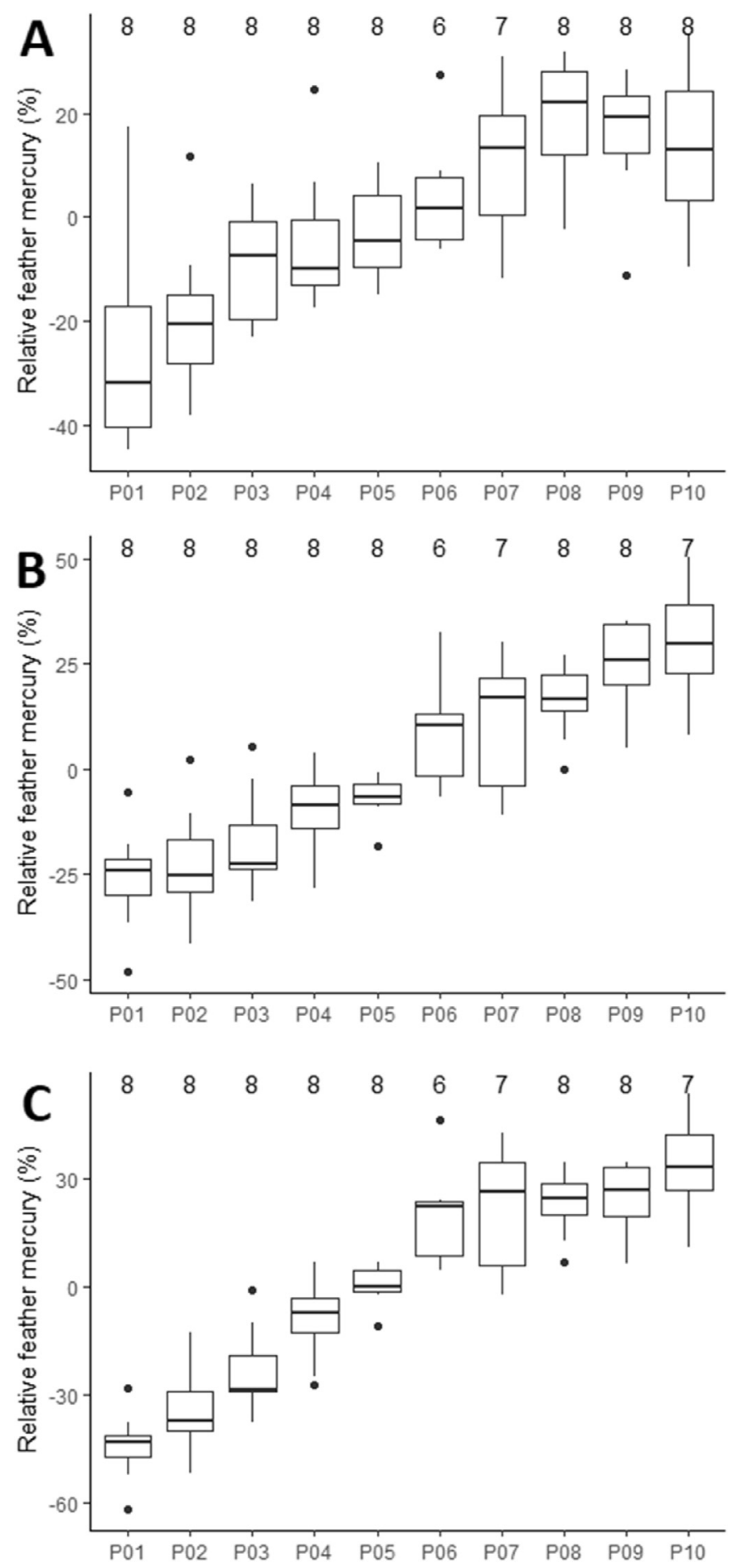

Fig. 4. The patterns of deviation in feather mercury concentration expressed as $\mu \mathrm{g}$ of mercury (A) per gram of feather, (B) per millimetre of feather, and (C) per day of feather growth increase from the innermost (P01) to the outermost (P10) primary similarly across all three measures in Bulwer's Petrel chicks. Relative mercury concentrations are presented as the deviation (\%) in a feather's mercury concentration from the mean feather mercury concentration of all analysed primaries in an individual. Sample sizes are presented above each box.

descending order from P10 to P1. As a result, blood mercury would have already been deposited in the growing outer primaries before the inner primaries start to grow. This is further corroborated by the similar mercury loads of the outermost segment of P1 and the third or fourth segments of distal feathers which were growing at 


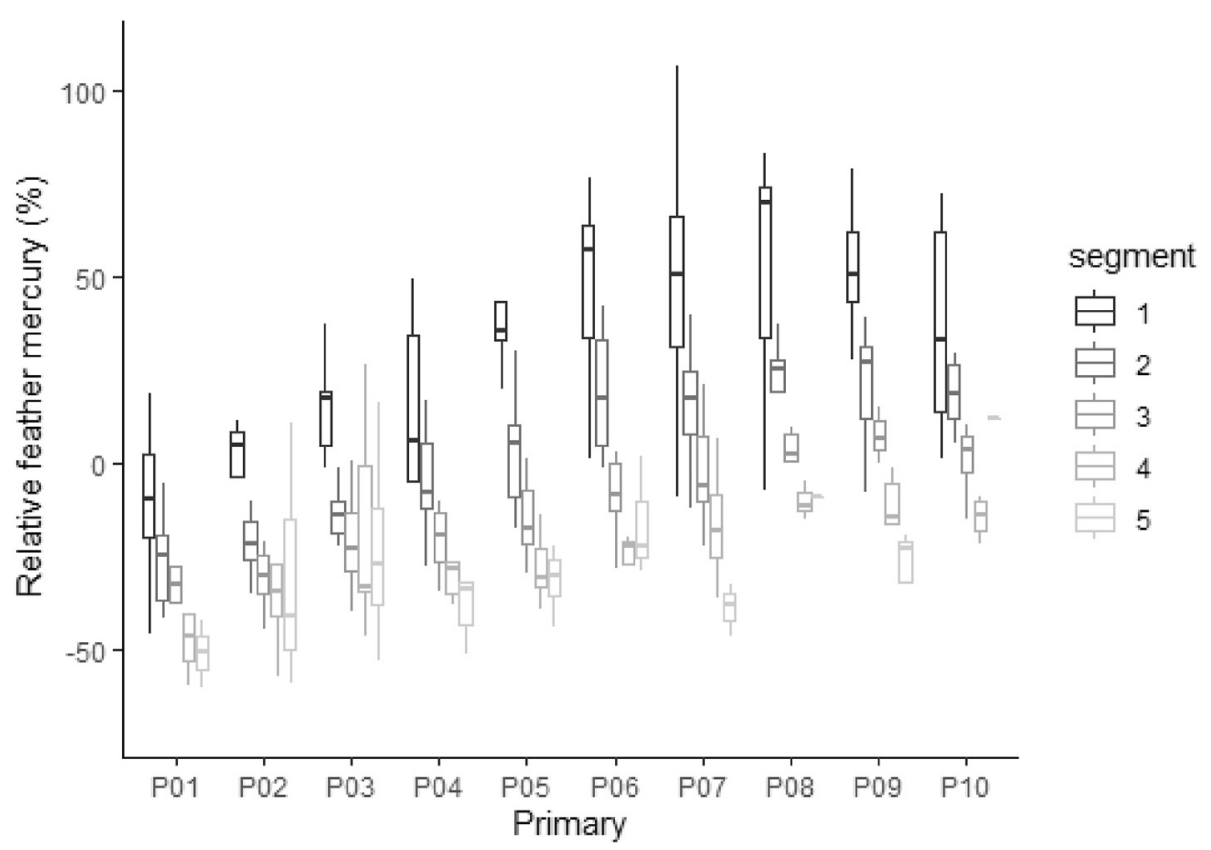

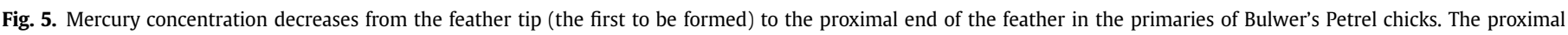

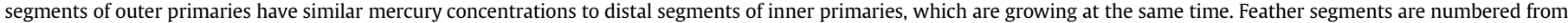
the most distal (1) to the most proximal (5) sampled position of the feather.

the same time.

Our results unambiguously refute the idea that the pattern in primary feather mercury is only an artefact of the unit of concentration used (Bortolotti, 2010). Taking a time-dependent measure of feather mercury concentration in Bulwer's Petrel feathers to address the theory proposed by Bortolotti (2010), either by measuring mercury concentration expressed as $\mu$ g of mercury per millimetre of feather or by transforming it into a rate of mercury deposition, does not account for the variation in mercury in primaries, which persisted. Rather, it seems to have made the pattern clearer, which supports the idea that mercury does indeed enter the feather structure in a time-dependent manner (Bortolotti, 2010).

Similar conclusions were reached by Carravieri et al. (2014) in comparisons of mercury concentrations between synchronously growing body feathers of juvenile White-chinned Petrels Procellaria aequinoctialis and adult King Penguins Aptenodytes patagonicus and body feathers of adult Antarctic Prions Pachyptila desolata, which moult sequentially over a prolonged period of time. The higher inter-feather variation in mercury concentration seen in adult Antarctic Prion body feathers suggested that the timing of feather growth does indeed have consequences on feather mercury deposition. Our results build up on this as they evidently show this effect in feathers of a known growth order in juveniles which have no geographical between-feather variation. Previous attempts to characterise mercury deposition in juvenile flight feathers were inconclusive in this regard and did not directly test for the timedependent deposition of mercury (Roque et al., 2016).

Very little is known on the moulting order in small petrels, except that primary moult occurs in the non-breeding area and is possibly arrested during migration (Bridge, 2006; Monteiro, Ramos, Furness, \& del Nevo, 1996). However, primary feather isotope data from adult Bulwer's Petrels generally support the notion that the order of primary moult is descendent (Cruz-Flores et al., 2018), as in shearwaters (Ramos et al., 2009b). Their results also suggest that outer secondaries and outer rectrices are moulted later than primaries (Cruz-Flores et al., 2018). While many moult patterns appear to be similar across avian taxa, species-specific differences in moult chronology could alter the importance of the body load of mercury in shaping a given feather's mercury concentration.

\section{Conclusion}

Our findings confirm that primary mercury concentrations do reflect mercury accumulated prior to feather growth (Ramos et al., 2009a; Thompson et al., 1998), more so in early grown or moulted feathers, such as proximal primaries in the adults of most bird species which carry the highest mercury loads. As a result, studies monitoring mercury exposure, particularly those interested in assessing mercury intake in discrete life history stages and/or in particular geographical areas in the case of migratory species, are advised to avoid feathers that are among the first to be moulted.

\section{Author contributions}

MCG and PC conceptualised the study and planned the methodology, RF and DL carried out the fieldwork, RF, and MCG carried out the sample preparation and supervised the sample analysis, MCG analysed the data and led the writing of the manuscript, PC, JPG, and EP supervised the study, all authors were involved in the reviewing and editing of the manuscript.

\section{Declaration of competing interest}

The authors declare that they have no known competing financial interests or personal relationships that could have appeared to influence the work reported in this paper.

\section{Acknowledgements}

We would like to thank Ana Barbosa for her contribution to the mercury analyses at the University of Aveiro. Instituto das Florestas e da Conservação da Natureza gave permissions and support for the work on Deserta Grande. Procedures were carried out under 
licenses issued by the Direção Geral de Alimentação e Veterinária, license number DGAV 0421/2017, and by the Instituto das Florestas e da Conservação da Natureza, IFCN licence $\mathrm{N}^{\circ} 4 / 18 \mathrm{D}$. Funding was provided by the Fundação para a Ciência e a Tecnologia (FCT, Portugal) through projects Seamigrant PTDC/BIA-ANM/3743/2014 and Oceanwebs (PTDC/MAR-PRO/0929/2014), and PD/BD/127807/ 2016 awarded to MCG. Thanks are due for the financial support to CESAM (UIDB/50017/2020 and UIDP/50017/2020) and MARE (UIDB/04292/2020 and UIDP/04292/2020) by FCT, Portugal.

\section{References}

Albert, C., Renedo, M., Bustamante, P., Fort, J., 2019. Using blood and feathers to investigate large-scale $\mathrm{Hg}$ contamination in Arctic seabirds: a review. Environ. Res. 177 (July), 108588. https://doi.org/10.1016/j.envres.2019.108588.

Appelquist, H., Asbirk, S., Drabæk, I., 1984. Mercury monitoring: mercury stability in bird feathers. Mar. Pollut. Bull. 15 (1), 22-24. https://doi.org/10.1016/0025326X(84)90419-3.

Bond, A.L., 2010. Relationships between stable isotopes and metal contaminants in feathers are spurious and biologically uninformative. Environ. Pollut. 158 (5), 1182-1184. https://doi.org/10.1016/j.envpol.2010.01.004.

Bortolotti, G.R., 2010. Flaws and pitfalls in the chemical analysis of feathers : bad news - good news for avian chemoecology and toxicology. Ecol. Appl. 20 (6), 1766-1774. https://doi.org/10.1890/09-1473.1.

Braune, B., Gaskin, D., 1987. Mercury levels in Bonaparte's gulls (Larus philadelphia) during autumn molt in the Quoddy region, New Brunswick, Canada. Arch. Environ. Contam. Toxicol. 549, 539-549. https://doi.org/10.1007/BF01055810.

Bridge, E.S., 2006. Influences of morphology and behavior on wing-molt strategies in seabirds. Mar. Ornithol. 34 (1), 7-19.

Burger, J., 1994. Metals in avian feathers: bioindicators of environmental pollution. In: Hodgson, E. (Ed.), Reviews in Environmental Toxicology and Applied Pharmacology, 5:203-311.

Carravieri, A., Bustamante, P., Churlaud, C., Fromant, A., Cherel, Y., 2014. Moulting patterns drive within-individual variations of stable isotopes and mercury in seabird body feathers: implications for monitoring of the marine environment. Mar. Biol. 161 (4), 963-968. https://doi.org/10.1007/s00227-014-2394-X.

Catry, P., Dias, M.P., Catry, T., Pedro, P., Tenreiro, P., Menezes, D., 2015. Bulwer's petrels breeding numbers on the Desertas Islands (Madeira): improved estimates indicate the NE Atlantic population to be much larger than previously thought. Airo 23, 10-14.

Chaurand, T., Weimerskirch, H., 1994. Incubation routine, body mass regulation and egg neglect in the Blue Petrel Halobaena caerulea. Ibis 136, 285-290.

Chételat, J., Ackerman, J.T., Eagles-Smith, C.A., Hebert, C.E., 2020. Methylmercury exposure in wildlife: a review of the ecological and physiological processes affecting contaminant concentrations and their interpretation. Sci. Total Environ. 711 https://doi.org/10.1016/j.scitotenv.2019.135117.

Cramp, S., Simmons, K.E.L., 1985. Handbook of the Birds of Europe, the Middle East and North Africa: the Birds of the Western Palearctic, vol. IV. Oxford Univeristy Press, Oxford, UK. Terns to Woodpeckers.

Crewther, W.G., Fraser, R.D.B., Lennox, F.G., Lindley, H., 1965. The chemistry of keratins. Adv. Protein Chem. 20 (C), 191-346. https://doi.org/10.1016/S00653233(08)60390-3.

Cruz-Flores, M., Militão, T., Ramos, R., Gonzalez-Solis, J., 2018. Using marine isoscapes to infer movements of oceanic migrants: the case of Bulwer's petrel, Bulweria bulwerii, in the Atlantic Ocean. PloS One 13 (6),1-13. https://doi.org/ 10.1371/journal.pone.0198667.

Dauwe, T., Bervoets, L., Pinxten, R., Blust, R., Eens, M., 2003. Variation of heavy metals within and among feathers of birds of prey: effects of molt and external contamination. Environ. Pollut. 124 (3), 429-436. https://doi.org/10.1016/ S0269-7491(03)00044-7.

Furness, R.W., Muirhead, S.J., Woodburn, M., 1986. Using bird feathers to measure mercury in the environment: relationships between mercury content and moult. Mar. Pollut. Bull. 17 (1), 27-30.

Gatt, M.C., Reis, B., Granadeiro, J.P., Pereira, E., Catry, P., 2020. Generalist seabirds as biomonitors of ocean mercury: the importance of accurate trophic position assignment. Sci. Total Environ. 740, 140159. https://doi.org/10.1016/ j.scitotenv.2020.140159.

Lewis, S.A., Furness, R.W., 1991. Mercury accumulation and excretion in laboratory reared black-headed gull Larus ridibundus chicks. Arch. Environ. Contam. Toxicol. 21 (2), 316-320. https://doi.org/10.1007/BF01055352.

Lindberg, P., Odsjö, T., 1983. Mercury levels in feathers of peregrine falcon Falco peregrinus compared with total mercury content in some of its prey species in Sweden. Environ. Pollut. B Chem. Phys. 5 (4), 297-318. https://doi.org/10.1016/ 0143-148X(83)90023-X.

Mallory, M.L., Braune, B.M., Provencher, J.F., Callaghan, D.B., Gilchrist, H.G., Edmonds, S.T., et al., 2015. Mercury concentrations in feathers of marine birds in Arctic Canada. Mar. Pollut. Bull. 98 (1-2), 308-313. https://doi.org/10.1016/ j.marpolbul.2015.06.043.

Martínez, A., Crespo, D., Fernández, J.Á., Aboal, J.R., Carballeira, A., 2012. Selection of flight feathers from Buteo buteo and Accipiter gentilis for use in biomonitoring heavy metal contamination. Sci. Total Environ. 425, 254-261. https://doi.org/ 10.1016/j.scitotenv.2012.03.017.

Monteiro, L.R., Furness, R.W., 2001. Kinetics, dose-response, and excretion of methylmercury in free-living adult Cory's Shearwaters. Environ. Sci. Technol. 35 (4), 739-746. https://doi.org/10.1021/ES000114A.

Monteiro, L.R., Ramos, J.A., Furness, R.W., del Nevo, A.J., 1996. Movements morphology, breeding, molt, diet and feeding of seabirds in the azores. Colon. Waterbirds 19 (1), 82-97.

Nunes, M., 2000. New data on the Bulwer's petrel breeding biology in the desertas islands (Madeira archipelago). Arquipel. Life Mar. Sci. Supplement, 167-173.

Nunes, M., Vicente, L., 1998. Breeding cycle and nestling growth of Bulwer's petrel on the desertas islands, Portugal. Colon. Waterbirds 21 (2), 198-204.

Peterson, S.H., Ackerman, J.T., Toney, M., Herzog, M.P., 2019. Mercury concentrations vary within and among individual bird feathers: a critical evaluation and guidelines for feather use in mercury monitoring programs. Environ. Toxicol. Chem. 38 (6), 1164-1187. https://doi.org/10.1002/etc.4430.

R Core Team, 2019. R: A Language and Environment for Statistical Computing. R Foundation for Statistical Computing, Vienna, Austria.

Ramos, R., González-Solís, J., Forero, M.G., Moreno, R., Gómez-Díaz, E., Ruiz, X., Hobson, K.A., 2009a. The influence of breeding colony and sex on mercury, selenium and lead levels and carbon and nitrogen stable isotope signatures in summer and winter feathers of Calonectris shearwaters. Oecologia 159 (2), 345-354. https://doi.org/10.1007/s00442-008-1215-7.

Ramos, R., Militão, T., González-Solís, J., Ruiz, X., 2009b. Moulting strategies of a long-distance migratory seabird, the Mediterranean Cory's Shearwater Calonectris diomedea diomedea. Ibis 151 (1), 151-159. https://doi.org/10.1111/j.1474919X.2008.00877x.

Roque, I., Lourenço, R., Marques, A., Coelho, J.P., Coelho, C., Pereira, E., et al., 2016. Barn owl feathers as biomonitors of mercury: sources of variation in sampling procedures. Ecotoxicology 25 (3), 469-480. https://doi.org/10.1007/s10646015-1604-8.

Shoji, A., Aris-Brosou, S., Fayet, A., Padget, O., Perrins, C., Guilford, T., 2015. Dual foraging and pair coordination during chick provisioning by Manx shearwaters: empirical evidence supported by a simple model. J. Exp. Biol. 218 (13) 2116-2123. https://doi.org/10.1242/jeb.120626.

Thompson, D.R., Bearhop, S., Speakman, J.R., Furness, R.W., 1998. Feathers as a means of monitoring mercury in seabirds: insights from stable isotope analysis. Environ. Pollut. 101 (2), 193-200. https://doi.org/10.1016/S0269-7491(98) 00078-5.

Varela, Z., García-Seoane, R., Fernández, J.A., Carballeira, A., Aboal, J.R., 2016. Study of temporal trends in mercury concentrations in the primary flight feathers of Strix aluco. Ecotoxicol. Environ. Saf. 130, 199-206. https://doi.org/10.1016/ j.ecoenv.2016.04.006.

Waap, S., Symondson, W.O.C., Granadeiro, J.P., Alonso, H., Serra-Gonçalves, C., Dias, M.P., Catry, P., 2017. The diet of a nocturnal pelagic predator, the Bulwer's petrel, across the lunar cycle. Sci. Rep. 7 (1), 1384. https://doi.org/10.1038/ s41598-017-01312-3.

Watanuki, Y., Yamamoto, T., Yamashita, A., Ishii, C., Ikenaka, Y., Nakayama, S.M.M., et al., 2015. Mercury concentrations in primary feathers reflect pollutant exposure in discrete non-breeding grounds used by Short-tailed Shearwaters. J. Ornithol. 156 (3), 847-850. https://doi.org/10.1007/s10336-015-1205-6.

Wischnewski, S., Arneill, G.E., Bennison, A.W., Dillane, E., Poupart, T.A., Hinde, C.A., et al., 2019. Variation in foraging strategies over a large spatial scale reduces parent-offspring conflict in Manx Shearwaters. Anim. Behav. 151, 165-176. https://doi.org/10.1016/j.anbehav.2019.03.014. 